\title{
PORTER'S FIVE FORCES ANALYSIS OF THE ORGANIC FARMING IN LAGUNA PROVINCE
}

\author{
Marivic B. Abinsay, DBA \\ Department of Education Schools Division Office Sta. Cruz Laguna \\ and San Pablo Colleges, Laguna \\ mavicb21@gmail.com
}

\begin{abstract}
This study assessed the external environment of the organic farming in Laguna Province, Philippines using Porter's five forces framework. Using snow ball approach for the selection of participants, a total of 86 organic farmers in selected municipalities were included in the study. A self-made questionnaire was the main data gathering tool. Frequency distribution and percentage were used to analyze data. Majority of the organic farms were existing for 3 to 5 years, less than one hectare farm size, vegetable as the prime commodity and manual organic farming practices. Based on Porter's five forces, threat of new entrants, threat of substitute and buyer power are high while supplier power and competitive rivalry are low. Results show that organic farming can be categorized as moderately attractive. Results suggest the need to intensify organic farming practices in the province of Laguna. The Porter's Five Forces Analysis can be used for better organic farming outcomes and boost the industry to induce farmers to shift from conventional agriculture to organic farming.
\end{abstract}

Keywords: organic farming, external environment, agriculture, Porter's Five Forces 


\section{Introduction}

Agriculture today places great strains on biodiversity, soils, water and the atmosphere, and these strains will be exacerbated if current trends in population growth, meat and energy consumption, and food waste continue. Likewise, awareness of the negative impacts of conventional agriculture to the environment, health, socio-economic and cultural well-being of people is gaining momentum with consumers around the world. Thus, organic agricultural systems deliver greater ecosystem services and social benefits (Reganold and Wachter, 2015). Organic agriculture (OA) is recognized to be the most popular alternative farming system because of the growing concern for health of the farmers, consumers, food safety and the environment (Crowder and Reganold, 2015). OA includes all agricultural system that promotes the environmentally, socially and economically sound production of food and fibers (IFOAM \& FIBL, 2015). With increasing concern about the environment, economic and social impact of chemical-dependent conventional agriculture, farmers and consumers seek alternative practices that will lead to green growth, profitability and livelihood sustainability (Dubey and Prasad, 2015). In the 1980s, social development groups in the Philippines implemented projects on sustainable agriculture because of perceived negative impacts of conventional farming on the environment (Rola, et.al., 2016). In terms of its agribusiness potentials, the organic agriculture industry in the Philippines has tremendous potential for growth. The demand for organic products makes new export opportunities. Organic farming is one export opportunity for small farmers who are well suited to partner with large businesses to market their products. Since organic agriculture is a promising technology to support environmental sustainability and rural development, the Philippines created into law the Organic Agriculture Act of 2010 (Republic Act 10068) which provides for the development of the country's organic agriculture (Rola, et al, 2016). It provides policy and governance structure and covers the operational policies of production and post-production support, market support, certification, labelling, local government unit support, research and development, extension, and capacity building.

In spite of a growing interest in organic agriculture, there has been relatively little research on why farmers might choose to adopt organic methods, particularly in the developing world (Olabisi, et al, 2015). Farmers have only low to medium level of 
awareness on organic farming activities and markets for organic products (Piadozo et al, 2014). With the increasing awareness of consumers for an alternative lifestyle and the enactment of Organic Agriculture Act of 2010, more and more farmers are expected to shift to organic farming in the Philippines. Despite the efforts of the Philippine government to promote organic agriculture, its adoption rate is still low (Pantoja, Badayos \& Rola, 2016). Shifting to organic farming and maintaining an organic farm are not easy tasks due to issues such as lack of knowledge on suitable production technologies, unstable supply, lack of markets, intensive labor inputs and difficulty in controlling weeds, pests and diseases (Shimoguchi and Mojica, 2016).

Along this venture, the province of Laguna supports the policy implementation on organic agriculture. Though there has been organic farming projects by universities and government agencies, organic agriculture in the province has apparently been slow in its uptake and majority of the farmers are still into conventional practices. In 2017, the documented practitioners of OA were 30 farmers only with an average area of 1 to 2 hectares of production area. Considering the efforts of the government and its implementation of Republic Act 10068, the growing demand for organic products and the advantages of organic farming, the adoption rate is still very low. Some organic farms were able to sustain operations such as Costales Natures Farm, which is the only certified organic farm remained in the business and continue to grow given the changing business environment (Shimoguchi and Mojica, 2016). Thus, exploring the organic farming industry in Laguna should be addressed in order to analyze the status, issues and problems of organic farming adoption through Porter's Five Forces.

\section{Literature review}

\subsection{Nature, Advantages and Challenges of Organic Farming}

OA includes all agricultural systems that promote the ecologically sound, socially acceptable, economically viable and technically feasible production of food and fibers. Considering the proven assurance of higher farm income than conventional agriculture (chemical-based farming), strong policy support from the government, increasing segment of the Philippine population shifting to a healthier lifestyle, and increasing awareness on the 
irreversible ill-effects of chemical-based agriculture on the environment (Colting and Tagarino, 2008). It dramatically reduces external inputs by refraining from the use of chemical fertilizers, pesticides and pharmaceuticals. It also covers areas such as but not limited to, soil fertility management, varietal breeding and selection under chemical and pesticide-free conditions, the use of biotechnology and other cultural and enhance productivity without destroying the soil and harming farmers, consumers and the environment.

In its uniqueness in farming, it is an integrated production management system which promotes and enhances agro ecosystem health, including biodiversity, biological cycles and soil biological activity (FAO, 2013). Organic production is a holistic system designed to optimize the productivity and fitness of diverse communities with the agro-ecosystem, including soil organisms, plants, livestock and people. It emphasizes the use of natural inputs (i.e. mineral and products derived from plants) and the renunciation of synthetic fertilizers and pesticides (Martin, 2009). In particular, it is intended to produce high quality and nutritious food which contributes to preventive health care and well-being. In view of this, it encourages the non-use of fertilizers, pesticides, animal drugs and food additives which may have adverse health effects. OA is developing rapidly and at some countries produce organic food commercially.

Considering the nature of organic farming, OA is becoming more popular because consumers are demanding healthy and environment-friendly food. This shift in consumer behavior is good news, but unfortunately increased demand for organic foods has attracted large agribusiness corporations that intend to profit from the trend. However, while organic agriculture may produce lower yields when compared to conventional agriculture especially at the start, organic farming is often more profitable, delivers more environmental benefits, and is healthier in terms of increased nutritional benefit and reduced dietary pesticide exposure. It is now being viewed as an additional option to conventional or 'chemical' agriculture and not just for the niche market (Maghirang, et al 2011).

\subsection{Assessment of External Factors based on Porter's Five Forces}

One of the models used to analyze the competitive environment in an industry with the aim of formulating strategies is the Porter's five forces model. This strategy is based on 
competition basis. Trying to gain more market share, competition is not only manifested in the actions of competitors, but competition in an industry is rooted in the principles of economic and competitive forces that are beyond the competitors. Customers, suppliers of raw materials and substitutes, competitive factors are all possible depending on the type of industrial fields, are more or less prominent and active (Bolorian and Rahmani, 2014). Despite some questions on today's applicability of Porter's Five Forces, the outcome of critical literature review shows that Porter's Five Forces cannot be considered as outdated. The basic idea that each company is operating in a network of Buyers, Suppliers, Substitutes, New Entrants and Competitors is still valid (Dälken, 2014).

As cited by Larry, Luis and Johnson (2014) in Porter (1979), Porter defines five distinct forces that have to be thought of when determining the attractiveness of a certain industry. Attractiveness, at this point, refers to the profitability the industry offers its entrant. According to the profitability, it should then be thought about if entering the industry is reasonable or should be avoided. The stronger these five forces are the less profit can be achieved in this specific industry and, hence, the less attractive this industry is to its potential entrant. Porter's Five Forces model is a powerful management tool for analyzing the current industry profitability and attractiveness by using the outside-in perspective. Globally, the use of Porter's Five Forces model involves a continuous process of environmental scanning and monitoring. There are various tools for analyzing the competitive environment such as the Five forces analysis, Game plan, Value Chain model, PESTEL model and the Strategic group analysis. Among the various strategic analysis tools, Porter's Five Forces Model has been perceived as the best (Dälken, 2014). The five competitive forces are constituted by the threat of new entrants, the threat of substitute products or services, the bargaining power of buyers, the bargaining power of suppliers and competitive rivalry.

\section{A. Threat of New Entrant}

The first force, threat of new entrant, examines how easy or difficult it is for competitors to join the marketplace in the industry being examined. The easier it is for a competitor to join the marketplace, the greater the risk of a business's market share being depleted. It is not only incumbent rivals that pose a threat to firms in an industry; the possibility that new firms may enter the industry also affects competition. 
A study on organic food perspective in developing countries showed that new entrants can pose a barrier. Current businesses may expand their activities, a potential barrier to new entries. The barriers to entry in the market can change depending governmental regulations and licensing. Potential entrants can be the existing businesses that may adopt their business strategy as well as new one (Matoshi and Veseli, 2017).

Analysis of the competitive environment of Thailand's sweet corn industry using Porter's Five Forces Model revealed that there is high competition for existing manufacturers. The competency of new entries depends on the level of the existing manufacturers' difficulties (Rachapila and Jansirisak, 2015). Likewise, Porter's five forces was used in analyzing the growing aquaculture industry in Kenya. The industry was moving at a significant rate due to the Government of Kenya's (GoK) Economic Stimulus Package (ESP) program promoting aquaculture with several subsidies, thus a rush into the input supply. The study showed that there is a high threat of new entrants but there are opportunities for existing agricultural shops to diversify into the supply of aquaculture products. However, there are high procurement costs due to declining quantities from the wild capture fisheries, and quality issues of farmed fish, which appears to scare off many potential new entrants (Ndanga, et al, 2015).

\section{B. Threat of Substitute}

The second force, threat of substitutes, is especially threatening when buyers can easily find substitute products with attractive prices or better quality and when buyers can switch from one product or service to another with little cost. This force studies how easy it is for consumers to switch from a business's product or service to that of a competitor. A close substitute product constrains the ability of firms in an industry to raise prices. The competition engendered by a Threat of Substitute comes from products outside the industry (Porter, 2008).

Substitutes are the products akin to others within the industry already produced. The reason why substitutes are offered by the firm and consumed by the customers may be either cheaper prices or non-availability of the original products. The purpose of substitutes is to increase the firm's competition in the market where it cannot compete with the same product. Local specific organic produced food is attractive to industry as long as it finds the way to 
the market. Of particular relevance are the laws regulating organic food and related to gastronomy. Pressure from substitute products include the large self-production and consumption by the families at home. The main substitute for an organic food product would be the low-priced regular grocery items or the non-organic products (Matoshi and Veseli, 2017).

On the input supply in Kenya's aquaculture, the threat of substitutes comes from inputs that are used for the capture fisheries and traditional agriculture that can also be used in aquaculture. The threat is high for the input supply sector because the industry is traditionally tied to the agricultural and fishery sectors. Therefore, many fishery and agricultural supply firms act as substitute suppliers. The main substitute to fish farming is capture fisheries. Other protein sources, such as chicken and beef, may also be substitutes for fish. The threat of substitute products is high for fish farming. However, as wild capture supply declines so does the threat. The declining threat of substitutes for fish farming could entice new entrants to join the sector, especially if they own land or have access to household land for pond construction. Opportunities exist to diversify into fingerling production to supply other farmers due to the low threat of substitutes given the few government accredited hatcheries and the respondents' assertion of the poor quality of wild caught fingerlings. The substitutes to fish market trading include fish shops, butcheries and supermarkets but the threat is low for fish marketing. There are relatively low barriers to entry and exit because of the existence of other formal fish retail options and consumers' preferences. Consumers often purchase fish from the open market, which allows for orders to be made according to specific customer preferences. Fingerlings that are caught from natural water bodies and fingerlings from government and private fish hatcheries are substitute products to the fish farming / input supply sector. However, fish farmers who perform their own breeding and hatchery activities (fish farming/ input supply) face low threats of substitutes because there are only a few accredited fish hatcheries (Ndanga, et.al., 2015).

\section{Buyer Power}

The third force, power of buyer, refers to the bargaining ability of customers to control a producer's or supplier's profitability. This is driven by the: number of buyers in the market; importance of each individual buyer to the organization; and cost to the buyer of 
switching from one supplier to another. Buyers exert strong or high bargaining power when: buying in large quantities or control many access points to the final customer, only few buyers exist, switching costs to other supplier are low, there are many substitutes, and buyers are price sensitive, when buyers have the ability to produce the same product or resources themselves instead of buying it from the suppliers, their power is also significant. Also, if buyers buy large volumes of products and are sensitive to lower prices their power is high. This specifically deals with the ability customers have to drive prices down. It is affected by how many buyers or customers a company has, how significant each customer is, and how much it would cost a customer to switch from one company to another (Porter, 2008). This element of the Five Forces analysis model refers to the effect of buyers on businesses. The bargaining power of a buyer moves in exactly the opposite direction as that of suppliers. Less number of buyers means the farmer often is a price taker, and hence has to settle for prices that are not always commensurate with the investment (both monetary and physical) the farmer has put in.

The power of buyers is the impact that customers have on a producing industry. This looks at the power of the consumer to affect pricing and quality. Consumers have power when there aren't many of them, but lots of sellers, as well as when it is easy to switch from one business's products or services to another. Buying power is low when consumers purchase products in small amounts and the seller's product is very different from any of its competitors. In a chicken meat study, results showed that for buyer power, demand is increasing for chicken meat, product is not unique and can be purchased from other suppliers; whole chicken and frozen chicken are homogenous products; and buyers base their decision mainly on price (De Oliveira, et. al., 2015). In an organic food study, the bargaining power of buyers included the customers frequenting the places where they can get certain organic and traditional food. Identified is at the restaurant it offers a greater variety (Matoshi Veseli, 2017).

\section{Supplier Power}

The fourth force, supplier power, is an assessment of how easy it is for suppliers to drive up prices. This is driven by the: number of suppliers of each essential input; uniqueness of their product or service; relative size and strength of the supplier; and cost of switching 
from one supplier to another. Strong bargaining power allows suppliers to sell higher priced or low quality raw materials to their buyers. This directly affects the buying firms' profits because it has to pay more for materials. Suppliers have strong bargaining power when; there are few suppliers but many buyers, suppliers are large and threaten to forward integrate, few substitute raw materials exist, suppliers hold scarce resources, and cost of switching raw materials is especially high (Porter, 2008). This force addresses how easily suppliers can drive up the price of goods and services. This element of the Five Forces analysis model identifies the degree at which suppliers impose their demands on business and the industry. The bargaining power of suppliers typically tends to be directly proportional to the number of players in the industry (though the correlation may not be exactly the same). The bargain power of suppliers shows the attractiveness of industry. If powerful suppliers are in the industry it will results low profit potential (Uenlue, 2018).

In the case of the sweet corn industry in Thailand, determinant of supplier power and the analyses of power of negotiation amongst sweet corn suppliers included supplier concentration. Having few suppliers and many buyers means that suppliers have power over the buyers in terms of price, quality, and other buying/selling terms; availability of substitute input where there are some restrictions in substitute products since there are not many varieties of sweet corn in Thailand and the availability of substitute inputs contributes to the high level of competitive force and effect (Rachapila and Jansirisak, 2015).

In Kenya's aquaculture, the bargaining power of suppliers for input supply and fish farming/input supply is high because good quality inputs are sourced internationally and prices are determined on the global market. There is, therefore, no price negotiation. However, the bargaining power of suppliers is high for fish farming because input suppliers and fish farmer/input suppliers supply raw materials to fish farmers and these are established sectors and often have some control on the prices they charge to the fish farming sector. Fish marketing usually includes traders of wild caught as well as farmed fish. However, farmed fish constitutes a small portion of fish products on the market; the majority is wild caught fish. Because farmed fish quantities are limited in markets, the main input suppliers for fish marketing are large scale wholesalers and middle men that bring the fish from the lake and farms. Suppliers appear to be in better negotiating positions with their customers due to the absence of formal contracts to the fish marketing sector. The high procurement costs that fish 
suppliers incur are passed on to fish marketers, which negates some of the positive effects of the low entry and exit barriers (Ndanga, et.al, 2015).

\section{E. Rivalry}

The fifth force concludes with the competitive rivalry which describes how the other four powers interrelate and shape the structure of competition within an industry. Putting together the impact of these forces, the level of competition as well as the profit potential and overall attractiveness and performance of an industry is determined. There are certain factors by which competitive rivalry is directly affected. If competing organizations are of approximately the same size, competitor balance will be such that rivalry will be intense. When industry growth rate is low, rivalry is likely to be intense. The existence of high fixed costs to operate in the industry and high exit barriers if a firm wishes to leave the industry will also trigger high rivalry. Additionally, when there is not significant differentiation between the product offerings of individual competitors, the level of rivalry will also be intense. Rivalry is the major determinant on how competitive and profitable an industry is. The main driver is the number and capability of competitors in the market. Many competitors, offering undifferentiated products and services, will reduce market attractiveness. In competitive industry, firms have to compete aggressively for a market share, which results in low profits. Rivalry among competitors is intense when: There are many competitors, exit barriers are high, growth of industry is slow or negative, products are not differentiated and can be easily substituted, competitors are of equal size, and low customer loyalty (Porter, 2008).

Along this end, agricultural production is characterized by a high degree of competitive rivalry. Efforts to develop branded or specialized products are quickly and effectively copied, and meaningful differentiation is difficult to achieve. Rivalry has a very detrimental impact on individual profitability in the sector An increasing and diverse demand, rapid adoption of new technologies, limitations on global agricultural resources, and a society with increasing expectations of agriculture to produce a safe, abundant, affordable — and now "sustainable"—supply of food, fiber, feed, and energy will all shape the future environment for crop producers. In addition, crop producers' ability to generate profits 
will change with the profitability prospects of input suppliers, customers, competitors, substitutes, and new entrants (Bechdol, Gray, \& Gloy, 2010).

In the rapid pace of competition in the current business environment, a firm or an industry is required to be more competitive and hostile. Competitiveness of the global agribusiness has raised concerns among economists and policy makers about the need for competitive advantage in the agribusiness sector of developing countries like. The concept of competitiveness could be viewed as an outcome and as such, superior economic or market performance is considered as an indicator of competitive advantage. Unique measurement of competitive advantage in agriculture sector hence provides supplementary value for identifying factors enhancing competitive advantage (Sachitra, 2017).

\section{Methodology}

The study used descriptive research method through the interview strategy. It particularly assessed the external environment of the OA in Laguna Province using a selfmade interview questionnaire as the main data gathering tool. The researcher, as an agriculturist herself, drafted the guide questions relevant to the Porter's Five Forces. The first part tackled the profile of the farm including the years of operation, farm size, types of produce and the organic farming practices. The second part comprised the in-depth interview on the five forces: threats of new entrants, threats of substitute, buyer power, supplier power and rivalry. The researcher probed the various practices as well as the personal assessment of the farm owners on the five forcers. The open-ended questions were supplemented with follow-up questions to gather in-depth analysis of the external environment.

The researcher personally facilitated the data gathering during the month of May 2017. Due to the limited official data from the provincial Department of Agriculture, the researcher started identifying popular and registered organic farms in the province. An official letter for interview request was sent and the schedule was set. The researcher visited the farm site to conduct the interview as well as farm tour for better experience of the actual farm practices. To compensate for the unavailability of the list of registered organic farms, the researcher opted to use snow ball approach in the selection of the participants. Each farm owner suggested another organic farmer within their area. At the end of the process, a total of 86 organic farmers in selected municipalities in Laguna were identified and visited. The 
researcher used voice recorder for the interview, checklist and guide questionnaires. The primary purpose of the study was explain to the farm owners prior to the interview proper. There were portions that the actual interview was facilitated during the farm tour. The farm owners presented the different aspects of their farms.

There were 86 organic farmers who contentiously participated in the study. Although there were other small organic farmers suggested, the researcher chose to include only those which were legally registered, structurally organized and enlisted farms in the provincial office. The basic profile of these farms is presented in the succeeding tables.

\section{Table 1}

Profile of the organic farms in Laguna Province

\begin{tabular}{cc|lc|lc}
\hline \hline \multicolumn{2}{c|}{ Years in operation } & \multicolumn{2}{|c|}{ Farm size (ha) } & \multicolumn{2}{c}{ Primary product } \\
\hline $0-2$ & F & & F & & F \\
$3-5$ & 30 & Less than 1 hectare & 49 & Rice & 35 \\
$6-8$ & 37 & 1.1 to 2.0 & 23 & Vegetables & 20 \\
$9-11$ & 12 & 2.1 to 3.0 & 4 & Fruits & 24 \\
$12-14$ & 2 & 3.1 to 4.0 & 4 & Livestock & 0 \\
$15-17$ & 3 & 4.1 to 5.0 & 1 & Fisheries & 2 \\
18 -above & 1 & More than 5 hectares & 5 & Dairy products & \\
\hline
\end{tabular}

Majority of the organic farms were in operation for up to five years with less than one hectare farm size and vegetables are the most planted commodity. In terms of the organic farming practices shown in Table 2, land preparation is usually manual with a percentage of $73.26 \%$ and lowest is mechanized with a percentage of $4.65 \%$. Seedling preparation is usually manual with the highest percentage of $95.35 \%$ and lowest in both mechanized and manual and mechanized with $2.33 \%$, respectively. Other manual practices include fertilization, irrigation, weed control, harvesting and post-harvest. 
Table 2

Organic Farming Practices in Laguna Province

\begin{tabular}{|c|c|c|c|c|c|c|}
\hline \multirow[t]{2}{*}{ Practices } & \multicolumn{2}{|c|}{ Manual } & \multicolumn{2}{|c|}{ Mechanized } & \multicolumn{2}{|c|}{$\begin{array}{c}\text { Manual \& } \\
\text { Mechanized }\end{array}$} \\
\hline & $\mathrm{F}$ & $\%$ & $\mathrm{~F}$ & $\%$ & $\mathrm{~F}$ & $\%$ \\
\hline Land preparation & 63 & 73.26 & 4 & 4.65 & 22 & 25.58 \\
\hline Seedling preparation & 82 & 95.35 & 2 & 2.33 & 2 & 2.33 \\
\hline Planting & 86 & 100.00 & & & & \\
\hline Direct seeding & 59 & 68.60 & & & & \\
\hline Broadcasting & 6 & 6.98 & & & & \\
\hline Transplanting & 48 & 55.81 & & & & \\
\hline Fertilization & 76 & 88.37 & 2 & 2.33 & 3 & 3.49 \\
\hline Vermiculture & 16 & 18.60 & & & & \\
\hline Composting & 37 & 43.02 & & & & \\
\hline Irrigation & 75 & 87.21 & 4 & 4.65 & 8 & 9.30 \\
\hline Weed control & 80 & 93.02 & 4 & 4.65 & 5 & 5.81 \\
\hline Pest control & 79 & 91.86 & 2 & 2.33 & 3 & 3.49 \\
\hline Harvesting & 78 & 90.70 & 4 & 4.65 & 4 & 4.65 \\
\hline Postharvest & 78 & 90.70 & 2 & 1.16 & 5 & 5.81 \\
\hline
\end{tabular}

The data gathered were tabulated using frequency distribution and percentage to determine the farming practices highly relevant to the five forcers of external environment analysis.

\section{Findings and Discussion}

\subsection{Threat of New Entrants: HIGH}

Table 3 shows the assessment of the external factors associated with the threat of new entrants. 
Table 3

The Identified Factors in the Threats of New Entrants

$\begin{array}{lll}\text { Threats } & \text { F }\end{array}$

\section{Other Products}

Genetically Modified Organisms (GMOs)

Aquaponic Products

Aeroponic Products

Hydroponic Products

\section{Start up challenges}

Capitalization

More manpower

Lower yield

Infestation

Access to inputs

Marketing
71

25

46

44

17

82

\section{Challenges on rules and regulations}

Industry structure

Institutional

Economical

Political/policies

Technological change
7

7

48

35
82.56

29.07

53.49

51.16

19.77

95.35

20.93

8.14

8.14

55.81

40.70

The major threat to organic products is the Genetically Modified Organism (GMO) and least is the aeroponic products. For the start-up challenges, majority consider marketing challenges, followed by capitalization and least in access to inputs. For the challenges on rules and regulations most of the participants answered political/policies as major challenge to them and least in the institutional and economical challenges.

Results show that the threat of new entrants is high considering that there are other existing products which are affordable and readily available. These products are very rampant and readily available in the market and are grown from the conventional methods. 
Since there are few players or producers, market is with high entry barrier and thus have a high profit margin. Since GMO produce are not segregated from the non-GMOs in the wholesalers' market, there is domestic skepticism that even organically certified locally produced poultry products, for example, could have eaten GMO corn. For the local consumers, it is not the organic certification that matters but the point of origin of the produce as it relates to shelf-life, possible presence of preservatives, and perhaps prevailing agricultural practices in the area (Carating and Tejada, 2012).

Supporting the findings, Khaledi et al, (2007) affirm that marketers, as important players in the market, have an important role for switching farmers between organic and conventional agriculture. Increasing organic farmers' satisfaction with their marketers improves organic practices, while decreasing conventional farmers' satisfaction with their marketers encourages them to switch to organic practices. Marketers, as market institutions, can improve organic farming adoption by advising on market and price prospects, providing advice on what to plant in new crop year, providing advice on market prospects based on the quality and quantity that farmers have grown, and providing farmers with agronomic information.

In the Philippines, the prevalent problems of rice farmers on access to organic inputs varied by type of farmers. Non-availability of quality seeds as well as delayed delivery of inputs were foremost among the problems faced by Certified Organic practitioners. The top three problem were the non-availability of organic fertilizer, lack of capital, non-availability of quality seeds and to some extent, the delayed delivery of inputs. The major production problems pertain basically to availability of inputs. In vegetable production, problems include the occurrence of pest and diseases, prevalence of typhoons and flood, and lack of irrigation water source. Organic farmers also had the highest share who experienced labor constraints due to high labor cost and lack of competent labor and poor work attitude of farmers. On reasons for not fully adopting rice organic farming practices, farmers claimed of not fully adopt organic farming because of lack of knowledge on the technology, reluctance to produce own fertilizer, organic farming is laborious, yield decreases and being accustomed to conventional farming. While reasons of those who are not adopting organic farming include the perception that organic farming produces low yield, poorly taught information on organic farming that lead to misconceptions, organic farming is time consuming particularly 
for farm workers and owners, reduced profit, attachment to the accustomed practice, and the intensity in farming tasks (Rola, et al, 2016).

\subsection{Threat of Substitute: HIGH}

\section{Table 4}

The Identified Factors in Threat of Substitutes

$\begin{array}{lll}\text { Threats } & \text { F }\end{array}$

\section{Alternative options to organic products are affected by:}

Demands

Price

Preference

Safety

Quality
34

54

10

13

21
39.53

62.79

11.63

24.42

Outsourcing alternative options to organic product by:

Contract growing

Local farmers

Cooperatives

Farmers' Associations
24

47

22

38
27.91

54.65

25.58

44.19

Highest among the reasons for substitution is price and lowest in preference. On outsourcing of the product, most of the participants answered local farmers and lowest in cooperatives. Results exhibit that the consumers can easily resort to purchase other products than organic if the price of organic products is high and products can be outsourced from local farmers.

The main substitute for an organic food product would be the low-priced regular grocery items. The reasons for consumers not to buy organic are informative as well. These are either non-availability of organic products, high price of organic products, or lack of trust that products labeled as organic are really produced organically (Herrman, 2010). 
In another study conducted by (Naspetti and Bodini, 2008), focus group interviews indicate that Italian consumers place much importance on the local origin of food products, especially if fresh consumed. The origin with its implication of seasonality, territoriality and localness are among the major motivating and trust factors, however not always linked to organic food products. Organic seems to suffer in global markets and localness may suggest a solution. The research provides insights on substitution and complementary marketing. Naspetti and Bodini (2014), stated that many consumers are interested in local products because of the perceived benefits of freshness, stronger taste and higher quality. To consumers, the origin attribute represents a strong purchasing criterion. With respect to organic produce, local food products may be perceived either as substitutes or as complementary. Furthermore, focus groups interviews indicate that Italian consumers place much importance on the local origin of food products, especially if fresh consumed. The origin with its implication of seasonality, territoriality and localness are among the major motivating and trust factors, however not always linked to organic food products. The lack of availability of local and organic food products together with retailing issues are taken into consideration.

\subsection{Buyer Power: HIGH}

Table 5 shows the identified external factors affecting the buyer power.

Majority of the participants answered there are many buyers in the market. For the type of buyers in the market, most of the participants answered local customer/businesses and lowest in processors/manufacturers. On factors affecting the price decrease of organic products, most of the participants answered over production and lowest in expanded services. While on factors affecting buyer's power to drive the price of organic products most of the participants answered substitute products such as inorganic products and lowest in preference. Results show that buyer power is high considering that there are many buyers in the market, and can choose substitute products such as inorganic products or other products with lower price, especially when there is overproduction. 
Table 5

The Identified Factors in Buyer Power

\section{Buyer Power}

F $\quad(\%)$

\section{Volume of Buyers in the Market}

Few

18.97

Many

33.33

Limited

Others

\section{Types of Buyers}

Local customers/businesses

Foreign customers

Other farmers

Exporters

Traders

Processors/manufacturers

$4 \quad 3.49$

Factors affecting the price decrease of organic products

Over Production

Low Demands

Perishability

Product Differentiation

Expanded Services

Factors affecting buyer's power to drive the price of organic products

Demands

Substitute Products such as inorganic products

Preference

Seal/Brand

Safety

Quality

Siding the results, acceptance of organically grown products is not yet high among consumers. Although there is some degree of knowledge and awareness about organic products and the ensuing issues about organic foods as against those produced under conventional farming practices, there is lack of appreciation by consumers on what it could contribute to food quality attributes, thereby influencing the premium price the consumer is willing to pay. The market remains limited for the highly educated and the health-conscious. Domestic consumers, the target market of the small farm holders, are not likely to be interested on the organic label. Integrated Pest Management (IPM) and organic produce are 
oftentimes judged by the presence of cosmetic blemishes. Presence, for instance, of insect bites in leafy vegetables is an indication that no pesticide was used; and would be preferred over the no-insect bite regardless of which has the organic certification (Carating and Tejada, 2012).

Buyers can be reached easily by increasing the availability of organic products; for example, consumers can get them in shops where they usually buy their groceries. The other two reasons why consumers refrain from buying organic products can be tackled by communication and promotion campaigns that increase consumers' awareness about and confidence in organic products (Herrman, 2010). While to Porter (2008), the power of buyers means their ability to force and influence the prices down by rising quality expectations or by comparison shopping. Rachapila and Jansirisak (2013) analysis of the environment of Thai sweet corn industry using Porter's Five Forces Model found that while factors affecting the buyers' negotiation power are the non-difference in products, and low switching cost.

In terms of quality, organic (certified) food is less trustworthy than local (conventional) farmers' products. They believe they can better trust local farmers because of the consumers-farmers proximity. Farmers are perceived to be closer to them at two different levels: when considering the (smaller) physical distance and because of a(closer) relationships. Consumers can have their personal experience with the producer and eventually personally verify the way of production (Naspetti and Bodini (2014).

\subsection{Supplier Power: HIGH}

Table 6 details the external factors affecting the Supplier Power.

Majority of the participants answered that suppliers in the market are few. While on how suppliers hold the power to control, most of the participants answered limited supply. The external factors that contribute to the strong or high bargaining power of suppliers are as follows: there are few suppliers, there is limited supply, and buyers are many and can switch easily to other products. Results indicate that the bargaining power of supplier is high since the suppliers are few and there is limited supply. Thus, the premium price of organic products.

Findings were supported by the study conducted by Rola et al, (2016), the marketing system of organic rice and organic vegetables determines its market structure, market 
conduct, and market performance. Dimensions of market structure are the degree of seller concentration or the number and size distribution of sellers in the market, degree of buyer concentration, degree of products differentiation, entry/exit condition, and the extent of market knowledge. In general, the number of sellers can affect the price received by the farmers causing a change in their output. On the other hand, the number of buyer can influence the price that they receive by changing the quantity being purchased. Product differentiation indicates some preferences of buyers to the other goods based on quality or other criteria.

\section{Table 6}

The Identified Factors in Supplier Power

Supplier Power $\quad$ F $\%$

\section{Suppliers in the Market}

Few

44

15

36

Limited

Factors driving the price of organic products

Limited Supply

Quality

18

Certification
51.16

17.44

41.86

56.98

20.93

41.86

In the same point of view, Rachapila and Jansirisak (2013) analyzed the environment of Thai sweet corn industry using Porter's Five Forces Model, it was found that Factors affecting the sellers' negotiation power are density of growers, difficulty of obtaining substitutes. In terms of safety, especially for products of animal-origin, the organic attribute (being certified) embeds a higher trust content. Local food suppliers should be studied in connection with consumers to have deeper knowledge of different perceptions of local (and eventually organic) products characteristics. (Naspetti and Bodini, 2014).

As cited by Rachapila and Jansirisak (2015) in Liang et al., (2007) competitive force is a factor influencing organization's contest within the industry and market. Small and medium entrepreneurs can soundly demonstrate Porter's principle of competition intensity. 
The basic consequences derive from the industry. The competitive force from both internally and externally contributes to performance. Rachapila and Jansirisak (2015) further cited in Low and Cheng, (2006) that direct consequence of the competitive force contributes to strategy making and organizational activities.

\subsection{Rivalry: $L O W$}

Table 7 explains the external factors in terms of rivalry.

\section{Table 7}

The Identified Factors in Rivalry

\begin{tabular}{lll}
\hline \multicolumn{1}{c}{ Rivalry } & F & $\%$ \\
\hline Level of Competition & 27 & \\
High & 20 & 31.40 \\
Low & 39 & 23.26 \\
Average & & 45.35 \\
Competitor Description & 45 & \\
Diverse & 25 & 52.33 \\
Concentrated & 20 & 29.07 \\
Similar & & 23.26 \\
Competitive advantage & 74 & \\
Certification/Seal & 16 & 86.05 \\
Product/service differentiation & 18 & 18.60 \\
Channel of distribution & & 20.93 \\
\hline
\end{tabular}

For the level of competition majority of the participants answered average. Majority of them also answered that the competitor situation is diverse and competitive advantage is on certification/seal.

Results show that the competitive rivalry is low since the level of competition is average, the competition is diverse and competitive advantage is on the certification/seal which the farmers do not have. Similarly, Rachapila and Jansirisak (2015) posed that rivalry 
among existing firms is a threat to existing manufacturers as the market shares will decrease. War price will also lead to lower profits. Nevertheless, organic certification is important because it helps in building trust between consumers and organic farmers; the certification mark 'Organic' is the only means to differentiate between certified organic and conventional foods; labels and certification marks help a consumer recognize trustworthy organic products easily; organic certification and the logo are important marketing tools; and organic certification helps in getting comparatively better price (Bhargava, 2010).

At this point, threat of established rivals in Ndanga, et.al (2015) study is high for the input supply sector. Aquaculture equipment is mostly sourced from established firms that provide the same harvest and fishing equipment to commercial fishermen, and provide irrigation and greenhouse equipment to horticulturists. Government and private fish hatcheries constitute established rivals to the fish farming/input supply sector. The threat of established rivals is generally medium for the fish farming/ input supply sector but high for those fish farmer/input suppliers in close proximity to large scale fish hatcheries. The threat to fish farming is high because established farmers have higher efficiencies in production, operate on larger scales of production, and have established markets. The input supply and fish farming sectors particularly require substantial investments in equipment and technological skills to achieve the efficiency. For fish marketing, the threat is also high because of the relationship based nature of contract marketing. Traders that have been operating for longer periods have established stronger ties with suppliers and consumers. The bargaining power of customers of fish marketing and fish farming is dependent on the size of the market and the location. The customers of fish farmers typically live in the same community as the farmers. Small portions of farmed fish make it to formal markets, to other small scale fish processors, restaurants, hotels and institutions, or final consumers. Customers of fish farmers in large market areas and provinces where wild capture fish is readily available have more bargaining power than those in small rural areas. Due to the absence of formal promotion and the fact that fish is a homogenous product, customers have freedom to demand and negotiate for lower prices. In this way, customers are considered to have high bargaining power in the fish marketing sector and medium power in the fish farming sector.

In general, for the industry to be attractive, the threat of new entrants must be high, threats of substitute must be low, power of buyers must be strong/high, power of suppliers 
must be weak/low, and competitive rivalry must be low.

Results of the five forces analysis is summarized in Figure 1.

\section{Figure 1}

Five Forces Competition Model of the Organic Farming Industry in Laguna Province

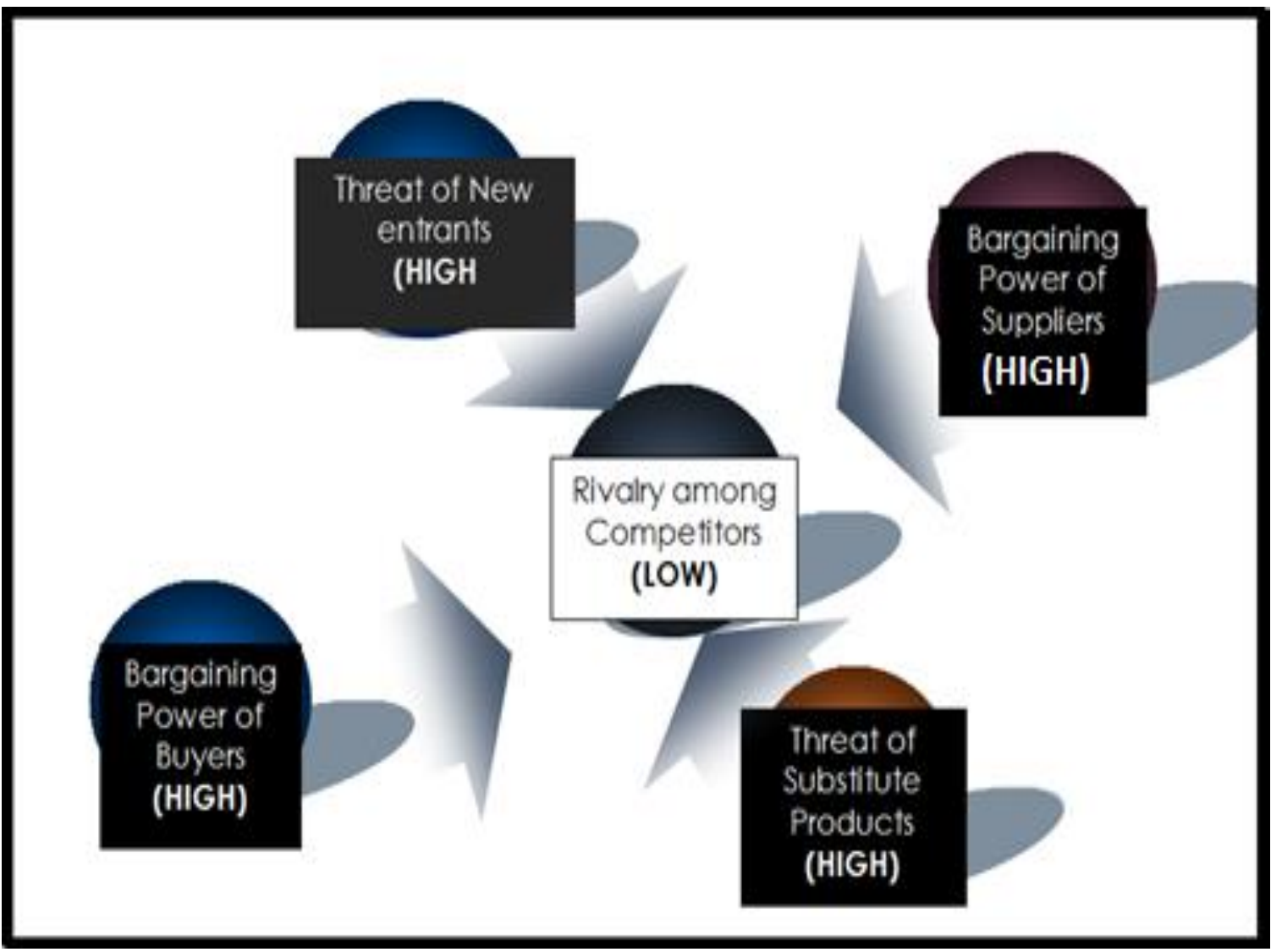

Results show that the organic farming industry in Laguna is an attractive industry in terms of threat of new entrant and competitive rivalry. However, the threat of substitute, buyer power, and supplier are high that make it unattractive. Therefore it can be categorized as moderately attractive and needs more improvement to boost the industry so that farmers will really be interested to shift from conventional agriculture.

\section{Conclusion}

This study assessed the external environment of the organic farming in Laguna Province, Philippines using Porter's five forces framework. Using snow ball approach for the 
selection of participants, a total of 86 organic farmers in selected municipalities were included in the study. A self-made questionnaire was the tool used in the open-ended interview strategy. The data were presented quantitatively using frequency and percentage.

The status of the organic farming is small to medium-scale, vegetable-based, and practitioners are beginners. It is an attractive industry in terms of threat of new entrant and competitive rivalry. However, the threat of substitute, buyer power, and supplier are high that make it unattractive. Therefore it can be categorized as moderately attractive. The results of this study serve as backgrounder for both the potential organic farmers and government legislators in the continuous development of the industry. In reality, there is a strong need to intensify organic farming practices employed in the province. The Porter's Five Forces Analysis can be applied to boost the industry and induce farmers to shift from conventional agriculture to organic farming.

\section{References}

Bechdol, Elizabeth, Allan Gray, and Brent Gloy. (2010). Forces Affecting Change in Crop Production Agriculture. Choice, the Magazine of Food, Farm and Resources Issues. Agricultural and Applied Economics Association. 4th Quarter, 25 (4)

Bhargava, Sandeep. (2010). Organic Certification. Organic Agriculture and Agribusiness: Innovation and Fundamentals. Tokyo: Asian Productivity Organization

Bolorian, T.M. and F. Rahmani. (2014). Evaluation Strategy Michael Porter's five forces model of the competitive environment on the dairy industry (Case Study: Amoll Haraz Dvshh dairy company). American Journal of Engineering Research (AJER), Volume03, Issue-05, pp-80-85

Carating, R.B. and S.Q. Tejada. (2012). Sustainable Organic Farming in the Philippines: History and Success Stories. Bureau of Soils and Water Management, Elliptical Road, Diliman, Philippines.

Colting, R.D. and D.D. Tagarino. (2008). Status and Agribusiness Potentials of Organic Agriculture in the Philippines. J. ISSAAS Vol. 14, No 1:25-32

Crowder, D.W. and J.P. Reganold. (2015). Financial competitiveness of organic agriculture on a global scale. PNAS, Vol. 112, No. 24, pp 7611-7616. DOI: www. pnas.org./cgi/doi/10.1073/pnas.1423674112 
Dälken, F. (2014). Are Porter's Five Competitive Forces still Applicable? A Critical Examination concerning the Relevance for Today's Business. 3rd IBA Bachelor Thesis Conference, July 3rd, 2014, University of Twente, Faculty of Management and Governance. pp. 1-9.

De Oliveira, C.A., D. Pivoto, C. P. and Spanhol, V. F. D. Corte. (2015). Developments And Competitiveness Of Mozambican Chicken Meat Industry. RAIMED - Revista de Administração IMED, 5(2): 205-216, maio/ago. 2015 - ISSN2237-7956. Pp. 205-216

Dubey, Rajesh Kr and NidhiShukla. (2014). Organic Farming: An Eco-Friendly Technology and Its Importance And Opportunities in the Sustainable Development. International Journal of Innovative Research in Science, Engineering and Technology, Vol.3, Issue 3, March 2014.

FAO. (2013). Organic Agriculture, Environment and Food Security. FAO, Rome, Italy.

Herrmann, Gerald A. (2010). Marketing of Organic Products: Critical SUCCESS Factors. Organic Agriculture and Agribusiness: Innovation and Fundamentals. Tokyo: Asian Productivity Organization

IFOAM \& FiBL. (2015). The World of Organic Agriculture. Statistics and Emerging Trends 2015. International Federation of Organic Agriculture Movements (IFOAM), Bonn \& Research Institute of Organic Agriculture FiBL, Frick, pp. 50-66; 163-166.

Khaledi, M. (2007). Assessing the Barriers to Conversion to Organic Farming: An Institutional Analysis. Advancing Canadian Agriculture and Agri-Food Saskatchewan (ACAAFS). Department of Agricultural Economics University of Saskatchewan.

Larry, M. S. Luis and F. Johnson. (2014). The 5 Competitive Forces Framework In A Technology Mediated Environment. Do these forces still hold in the industry of the 21 st century? $3^{\text {rd }}$ IBA Bachelor Thesis Conference. University of Twente, Faculty of Management and Governance. July 3, 2014, Enschede, The Netherlands

Maghirang, R.G., R. De La Cruz, R.L. Villareal. (2011). How Sustainable is Organic Agriculture in the Philippines? Trans. Nat. Acad. Sci. \& Tech. (Philippines) Vol. 33, No. 2, pp. 289-321. 
Martin, H. (2009). Introduction to Organic Farming. Ontario: Queen's Printer for Ontario

Matoshi, Ruzhdi and Besa Veseli. (2017). Organic Food Perspective in Developing Countries: An Overview of Polog Region and a Case Study in the Republic of Macedonia. European Journal of Multidisciplinary Studies. Pp. 9-16

Naspetti, Simona and Antonella Bodini. (2014). Consumer Perception of Local and Organic Products: Substitution or Complementary Goods? The International Journal of Interdisciplinary Social Sciences: Annual Review. Volume 3, pp 1 - 13

Ndanga, LZB, K .Quagrainie, CC Ngugi, and J Amadiva. (2015). Application of Porter's Framework to Assess Aquaculture Value Chain in Kenya. African Journal on Food, Agriculture, Nutrition and Development, Vol. 15, No. 3. Pp. 1018-10137

Olabisi, L.S., R.Q. Wang, A. Ligmann-Zielinska. (2015). Why Don't Farmers Go Organic? Using A Stakeholder-informed Exploratory Agent-Based Model to Represent the Dynamics of Farming Practices in the Philippines. Land 2015, 4,979-1002: doi:10.3390/land4040979. ISSN 2073-445X. www.mdpi.com/journal/land.

Pantoja, Blanquita \& Badayos, Gerdino \& Rola, Agnes. (2016). Constraints to Adoption of Organic Rice Production in Selected Areas in the Philippines. A Technical Report. DOI: 10.13140/RG.2.2.31525.50401.

Piadozo, M.E.S., F.A. Lantican, I.M. Panuayon, A.R. Quicoy, A.M. Suyal, P.K.B. Maghirang. (2014). Rice Farmers' Concept and Awareness of Organic agriculture implications for sustainability of Philippine organic agriculture program. J.ISSAAS. Vol.20 No.2;142-156 (2014).

Porter, M. E. (2008). The Five Competitive Forces That Shape Strategy. Harvard Business Review, 86(1), 25-40.

Rachapila, T. and S. Jansirisak. (2013). Using Porter's Five Forces Model for Analysing the Competitive Environment of Thailand's Sweet Corn Industry. International Journal of Business and Social Research (IJBSR), Volume -3, No.-3, March 2013. pp. 174-184 
Reganold, J. P., \& Wachter, J. M. (2016). Organic agriculture in the twenty-first century. Nature plants, 2, 15221. https://doi.org/10.1038/nplants.2015.221Rola, Agnes C., Blanquita R. Pantoja, Agnes R. Chupungco, Miriam R. Nguyen, and Jaine C.

Rola, Agnes C., Blanquita R. Pantoja, Agnes R. Chupungco, Miriam R. Nguyen, and Jaine C. Reyes. (2016). Policy Support to Organic Agriculture in the Philippines. DA-BAR, Diliman, Quezon City, and UPLBFI, College, Laguna, Philippines, 215pp.

Sachitra, Vilani. (2017). Review of Competitive Advantage Measurements: Reference on Agribusiness Sector. Journal of Scientific Research and Reports. 12(6): 1-11.

Shimoguchi, Nina and Loida Mojica. (2016). Adaptation Strategies to Changing Environment by an Organic Farm in Laguna, Philippines. IJERD - International Journal of Environmental and Rural Development (2016) 7-2. Pp. 93-98

Uenlue, Murat. (2018). Strategy: Porter's Five Forces Explained. Retrieved from InnovationTactics.com 